\title{
Preparation and Characterization of ZnO Nanocrystalline for Photovoltaic Applications Using Laser Ablation Technique
}

\author{
Odai N. Salman ${ }^{1}$ and Ibrahim R. Agool ${ }^{2}$ \\ Physics Department, College of Sciences, Al-Mustansiriya University, Baghdad-Iraq. \\ E-mail: ${ }^{1}$ micro_ud@yahoo.com ${ }^{2}$ Dr.agoolir@yahoo.com.
}

\begin{abstract}
The synthesis of $\mathrm{ZnO}$ nanocrystalline by laser ablation of a pure zinc metal target in pure water are presented hear. X-ray diffraction (XRD) analysis show that the $\mathrm{ZnO}$ nanoparticle is having crystalline wurtzite phase. Transmission electron microscopy (TEM) image illustrate that the $\mathrm{ZnO}$ nanoparticles is spherical shape with an average size of about $37 \mathrm{~nm}$. Williamson-Hall $(\mathrm{W}-\mathrm{H})$ plot was employed to estimate the crystalline sizes and lattice strain. The optical energy gap were obtained from UV-Vis spectroscopy agreement with that obtained from Photoluminescence spectra. The blue emission were observed when excited the suspension with $335 \mathrm{~nm}$. Dye-Sensitized Solar Cell (DSSC) was successfully fabricated from $\mathrm{ZnO}$ nanoparticle using electrostatic deposition technique.
\end{abstract}

Keywords: ZnO nanocrystalline, Laser ablation, W-H analysis, DSSC.

\section{Introduction}

Metal oxides like $\mathrm{ZnO}$ and $\mathrm{TiO}_{2}$ play a very important role in many areas of chemistry, physics, and materials science. The metal elements can form a large assortment of oxide compounds. These elements can accept many structural geometries with an electronic structure that can display metallic, semiconductor, or insulator character [1]. Many synthesis methods are reported to produce $\mathrm{ZnO}$ nanoparticles, such as Nanoforest [2], hollow nanosphere [3], nanorod [4], Nanoflower [5], and so forth. Among them is the Pulse laser ablation technique, which was profitably developed as a gas-phase approach for metal and Oxide nanostructures. Laser ablation of solids in solution environment is a simple and adaptable method to produce nanoparticles [6]. The unique feature of laser ablation in liquid is the formation of dense plasma which brings about local and temporal non-equilibrium conditions. Accordingly, not only the chemical environment but also physical parameters including laser power and spot size, wavelength, and ablation time determine the characteristics of the resultant nanoparticles [7]. The chemical reactions in pure water can be expressed as follows [8]:

$$
\begin{aligned}
& Z n_{(\text {target })} \stackrel{\text { laser }}{\longrightarrow} Z n_{(\text {plasma })}^{+}+2 e^{-} \\
& Z n_{(\text {plasma })}^{+}+2 e^{-} \rightarrow Z n_{(\text {cluster })}
\end{aligned}
$$

$\mathrm{Zn}_{\text {(cluster) }}+2 \mathrm{H}_{2} \mathrm{O} \rightarrow \mathrm{Zn}(\mathrm{OH})_{2}+\mathrm{H}_{2} \uparrow \rightarrow$ $\mathrm{ZnO}+2 \mathrm{H}_{2} \mathrm{O}$

Because of the local high-temperature environment, the aqueous oxidation reaction is very intense for the highly active $\mathrm{Zn}$ clusters, leading to the formation of the initial oxidation product $\mathrm{Zn}(\mathrm{OH})_{2}$, which can easily be decomposed to $\mathrm{ZnO}$ because of the thermal effect. Here, we present experimental results on the preparation of $\mathrm{ZnO}$ nanoparticles via liquid laser ablation.

\section{Experimental}

$\mathrm{ZnO}$ nanoparticles were produced by laser ablation of a $\mathrm{Zn}$ target $(1 \times 1 \mathrm{~cm}$, purity of 99.99\%) was fixed at bottom of glass vessel containing of $3 \mathrm{ml}$ DDW. The plate was located at a distance of $3 \mathrm{~cm}$ from the solution surface in the solution, and then it was ablated for $30 \mathrm{~min}$ by the first harmonic of a Nd:YAG pulsed laser (wavelength $1064 \mathrm{~nm}$, pulse duration $9 \mathrm{~ns}$ ) with the power $650 \mathrm{~mJ} /$ pulse, and the spot size about $3 \mathrm{~mm}$ in diameter. The laser beam was focused on the $\mathrm{Zn}$ target using convex lens of $10 \mathrm{~cm}$ focal length to produce acceptable laser fluence for the ablation. Fig.(1) shows the experimental setup of PLAL system. The Dye sensitized photocell were fabricated by deposited $\mathrm{ZnO}$ suspension on FTO glass substrate using electrostatic deposition method to produce photoanode, the 
$\mathrm{ZnO}$ layer was processed in horizontal Furnace at temperature $600{ }^{\circ} \mathrm{C}$ for $30 \mathrm{~min}$. Dye (N719 from Dyesol Co.) loading then done by dipping $\mathrm{ZnO}$ film in $0.25 \mathrm{mM} \mathrm{N719}$ in ethanol for 24 hour. Platinum layer on ITO-Glass (counter electrode with two holes) were obtained after treating at $450{ }^{\circ} \mathrm{C}$ screen printed Pt-1 Dyesol pastes. The electrodes were sealed together with a Thermoplastic Sealant (MS004610 $30 \mu \mathrm{m}$ Surlyn, Dyesol) and finally a commercial electrolyte (EL-UHSE from Dyesol) was used to complete the device.

For transmission electronic microscopy (TEM Carl Zeiss - Germany - EM10 C- 100 $\mathrm{KV}$ ) examination, a droplet of the solution was placed on a carbon-coated copper grid. The characterizations with X-ray diffraction (shimadzu X-Ray Diffractometer XRD 6000 using the $\mathrm{Cu} \mathrm{KR}$ line $0.15419 \mathrm{~nm}$ ) were conducted for the $\mathrm{ZnO}$ film deposited on glass substrate by electrostatic deposition method. The PL spectra were measured with shimadzu Spectrofluoro photo meter (RF-5301PC) with Xe lamp excitation. The optical absorption were measured with T60 UV/VIS Spectrophotometer. The concentration of Zinc were measured with Atomic Absorption spectroscopy (phoenix-986).

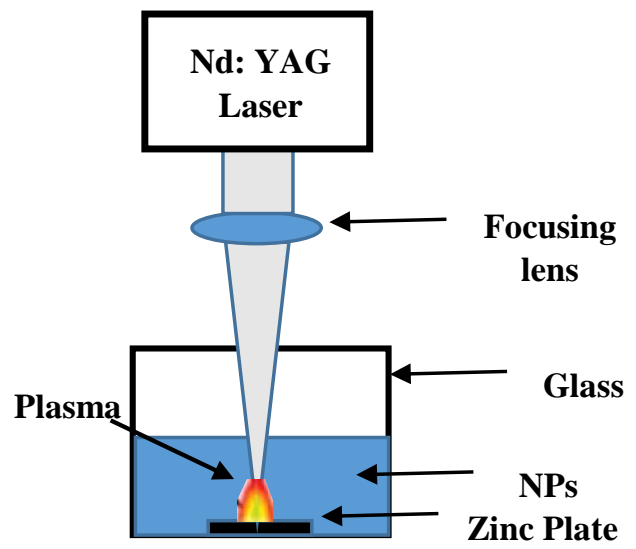

Fig.(1): Shows the experimental setup of PLAL system.

\section{Results and Discussion}

The XRD pattern of the $\mathrm{ZnO}$ nanoparticles prepared by laser ablation of a $\mathrm{Zn}$ target in deionized water at room temperature presented in Figure 2 disclose that they are crystalline and have the hexagonal wurtzite structure. In the $\mathrm{ZnO}$ hexagonal structure, the plane spacing $\mathrm{d}$ is related to the lattice constants a, c and the Miller indices by the following relation [9]:

$\frac{1}{d_{(h k l)}^{2}}=\frac{4}{3}\left(\frac{h^{2}+h k+k^{2}}{a^{2}}\right)+\frac{l^{2}}{c^{2}}$

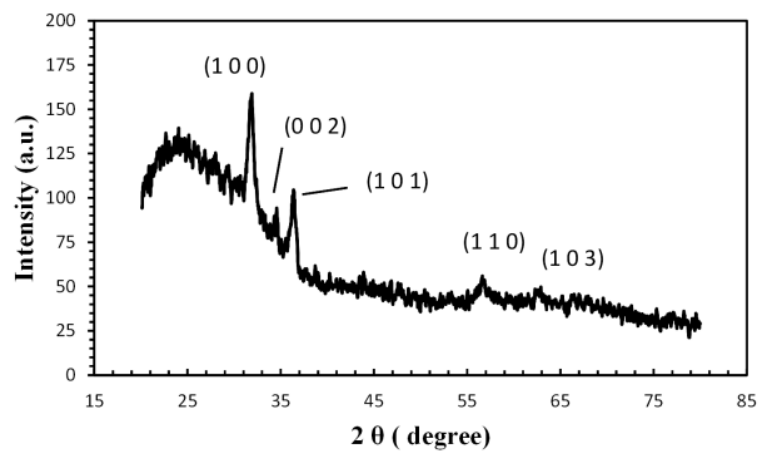

Fig.(2): XRD pattern of $\mathrm{ZnO}$ nanoparticles.

The lattice constants $(\mathrm{a}=\mathrm{b}=3.2500 \AA$ and $\mathrm{c}=5.1751 \AA, \mathrm{c} / \mathrm{a}=1.5923)$ and diffraction peaks corresponding to the planes $\langle 100\rangle$, $\langle 002\rangle,\langle 101\rangle,\langle 110\rangle,\langle 103\rangle$ obtained from $X$-ray diffraction data are consistent with the JCPDS data of $\mathrm{ZnO}$. The interplanar spacing $\left(d_{h k l}\right)$ calculated from XRD is compared with JCPDS data card and corresponding $\langle\mathrm{h} \mathrm{k} \mathrm{l}\rangle$ planes, percentage of variation of $\mathrm{d}$ and full width at half-maximum (FWHM) values for some major XRD peaks are summarized in Table (1).

Table (1)

Interplanar spacing $\left(d_{h k l}\right)$ from XRD, JCPDS card, percentage of variation of $d$, and FWHM.

\begin{tabular}{|c|c|c|c|c|}
\hline$\langle$ h kl $>$ & $\begin{array}{c}\text { dxRD } \\
(\AA)\end{array}$ & $\begin{array}{c}\text { dJCPDS } \\
(\AA)\end{array}$ & $\begin{array}{c}\% \text { of } \\
\text { contraction } \\
\text { in } \mathbf{d}\end{array}$ & $\begin{array}{l}\text { FWHM } \\
\text { (Degree) }\end{array}$ \\
\hline 100 & 2.8146 & 2.8143 & 0.01 & 0.73 \\
\hline 002 & 2.60212 & 2.6033 & 0.0012 & 0.32 \\
\hline 2101 & 2.47261 & 2.47592 & 0.133 & 0.6267 \\
\hline 10110 & 1.62703 & 1.62472 & 0.142 & 0.7 \\
\hline
\end{tabular}

The average nanocrystalline size was estimated using Scherrer's formula [10]:

$D=\frac{K_{S} \lambda}{\beta_{h k l} \cos \theta}$

where $D$ is the crystalline size, $K_{S}$ is the shape factor, for the case of a sphere $\mathrm{K}_{\mathrm{S}}=(4 / 3)(\pi / 6)(1 / 3)$ has been shown, and $\lambda$ is wavelength of Cuk $\alpha$ radiation. From the 
calculations. The strain induced in the film due to defects and imperfections was calculated using the formula [11]:

$$
\varepsilon=\frac{\beta_{h k l}}{4 \tan \theta}
$$

From Equations (5) and (6), It was confirmed that the peak width from crystallite size varies as $1 / \tan \theta$ strain varies as $\tan \theta$. Assuming that the particle size and strain contributions to line broadening are independent to each other and both have a Cauchy-like profile, the observed line breadth is simply the sum of Equations (5) and (6).

$\beta_{h k l}=\frac{K_{S} \lambda}{D \cos \theta}+4 \varepsilon \tan \theta$

By re-arranging the above equation, we get

$\beta_{h k l} \cos \theta=\frac{K_{S} \lambda}{D}+4 \varepsilon \sin \theta$

The above equations are Williamson-Hall $(\mathrm{W}-\mathrm{H})$ equations. A W-H plot is drawn with $4 \sin \theta$ along the $\mathrm{x}$-axis and $\beta \cos \theta$ along the $y$-axis as shown in Fig.(3). From the linear fit to the data, the crystalline size and the strain $\varepsilon$ were estimated for $\mathrm{ZnO}$ nanoparticles from the y-intercept and the slope; respectively. Equation 8 represents the uniform deformation model (UDM), where the strain was assumed to be uniform in all crystallographic directions, thus considering the isotropic nature of the crystal, where the material properties are independent of the direction along which they are measured. The uniform deformation model for $\mathrm{ZnO}$ nanoparticles is shown in Fig.(3). Table (2) summarizes the geometric parameters of $\mathrm{ZnO}$ nanoparticles obtained from Scherrer's formula, W-H analysis, and TEM results.

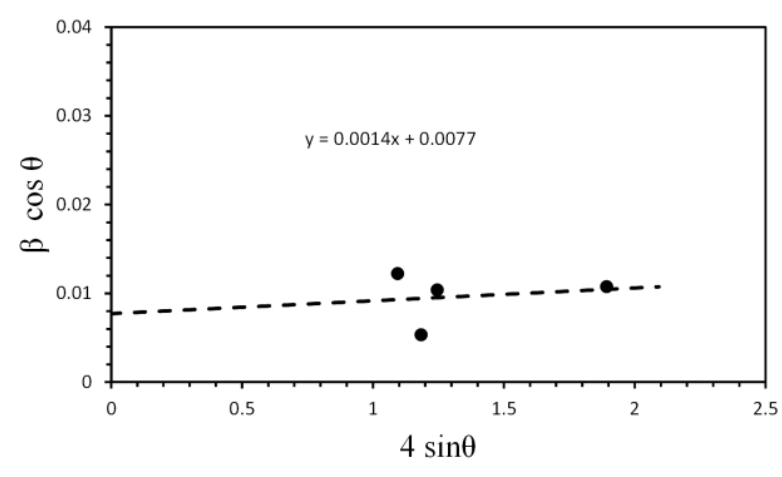

Fig.(3): Williamson Hall Plot for ZnO Nanoparticles.

Table (2)

Geometric parameters of the $\mathrm{ZnO}$ nanoparticles.

\begin{tabular}{|c||c||c|c|}
\hline $\begin{array}{c}\text { Scherrer's } \\
\text { method }\end{array}$ & \multicolumn{2}{|c|}{ W-H method } & TEM \\
\hline \hline $\mathbf{D}_{\text {ave }}(\mathbf{n m})$ & $\begin{array}{c}\mathrm{D} \\
(\mathrm{nm})\end{array}$ & $\begin{array}{l}\varepsilon \\
\times 10^{-4}\end{array}$ & $\mathrm{D}_{\text {ave }}(\mathrm{nm})$ \\
\hline \hline 16.6 & 20 & 14 & 37 \\
\hline
\end{tabular}

Nanoscale structures such as nanoparticles have very high specific surface area (SSA) may lead to a radical alteration in chemical reactivity. SSA is the SA per mass [12].

$S A A=\frac{6 \times 10^{3}}{\rho d} \quad$ Sphere of diameter $\mathrm{d}$

where, $\rho$ and $d$ are respectively the density of particle and diameter of the particle. SSA can be calculated using equation (9) and recited in Table (3).

Table (3)

Specific Surface Area of ZnO Nanoparticles.

\begin{tabular}{||c||c||c||c||c||c|}
\hline $\begin{array}{c}\text { Particle } \\
\text { Size } \\
(\mathbf{n m})\end{array}$ & $\begin{array}{c}\text { Surface } \\
\text { Area } \\
\left(\mathbf{n m}^{2}\right)\end{array}$ & $\begin{array}{c}\text { Volume } \\
\left(\mathbf{n m}^{\mathbf{3}}\right)\end{array}$ & $\begin{array}{c}\text { Density } \\
\left(\mathbf{g ~ c m}^{-3}\right)\end{array}$ & $\begin{array}{c}\text { SSA } \\
\left(\mathbf{m}^{\mathbf{2}} \mathbf{g}^{-1}\right)\end{array}$ & $\begin{array}{c}\text { SA to } \\
\text { Volume } \\
\text { Ratio }\end{array}$ \\
\hline \hline 37 & 4298.66 & 26508.4 & 5.61 & 28.9 & 0.162 \\
\hline
\end{tabular}

The dislocation density $(\delta)$, defined as the length of dislocation lines per unit volume of the crystal, was evaluated from the formula [13]

$$
\delta=\frac{1}{D^{2}}
$$

Where D is the crystallite sizes. 
A XRD morphology index (MI) is developed from FWHM of XRD data to understand this relationship. MI relates the FWHM of two peaks to its particle morphology (peak having highest FWHM and a particular peak's FWHM for which M.I. is calculated). Generally, highest FWHM peak MI is 0.5 because the MI is derived from the single peak only. MI is obtained using the following equation [14]:

$$
M I=\frac{F W H M_{h}}{F W H M_{h}+F W H M_{p}}
$$

where M.I is morphology index, $\mathrm{FWHM}_{h}$ is highest FWHM value obtained from peaks and $\mathrm{FWHM}_{p}$ is value of particulars peak's FWHM for which M.I is to be calculated. $\delta$ and M.I. for each orientation can be calculated using equation (10) and (11) and recited in Table (4).

\section{Table (4)}

Morphology Index and Dislocation Density of ZnO Nanoparticles.

\begin{tabular}{|c|c||c|c|c|}
\hline \hline h k l > & $\begin{array}{c}(\boldsymbol{\beta}) \\
\text { radians }\end{array}$ & $\begin{array}{c}(\mathbf{D}) \\
(\mathbf{n m})\end{array}$ & $(\mathbf{M I})$ & $\begin{array}{c}\boldsymbol{\delta} \times \mathbf{1 0}^{\mathbf{1 5}} \\
\left(\mathbf{m}^{-2}\right)\end{array}$ \\
\hline \hline $\mathbf{1 0 ~ 0}$ & 0.0127344 & 12.5 & 0.5 & 6.4 \\
\hline $\mathbf{0 ~ 0 2}$ & 0.0055822 & 28.8 & 0.695 & 1.2 \\
\hline \hline $\mathbf{1 0 1}$ & 0.0109324 & 14.8 & 0.538 & 4.5 \\
\hline \hline $\mathbf{1 1 0}$ & 0.0122111 & 14.3 & 0.51 & 4.9 \\
\hline
\end{tabular}

Fig.(4) presents the Transmission electron microscope (TEM) image comparable to the sample shown in Fig.(2). The results are composed of the particles with nearly spherical shape. The average size of $\mathrm{ZnO}$ nanoparticles is about $37 \mathrm{~nm}$.

Atomic absorption spectrometer (AAS) was employed to get relation between concentration of $\mathrm{ZnO}$ nanoparticles and laser shots, Fig.(5).

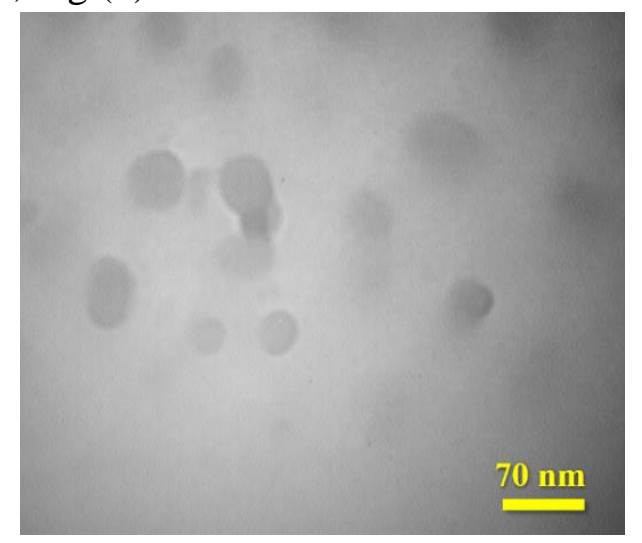

Fig.(4): TEM image of $\mathrm{ZnO}$ nanoparticles.
Show the amount of $\mathrm{ZnO}$ nanoparticles as a function of laser shots, comparable to the samples shown in Fig.(6).

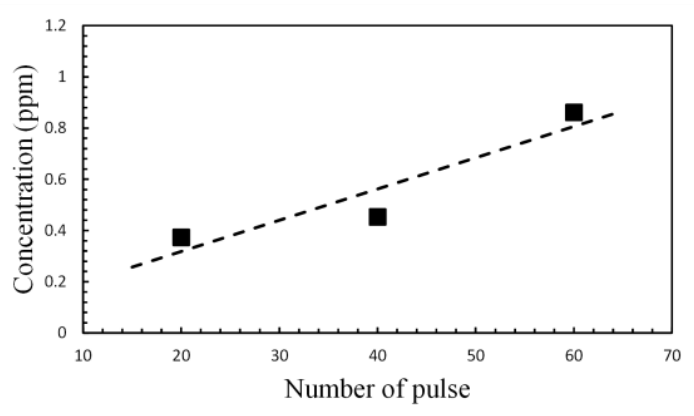

Fig.(5): ZnO concentration as a function of laser shots.

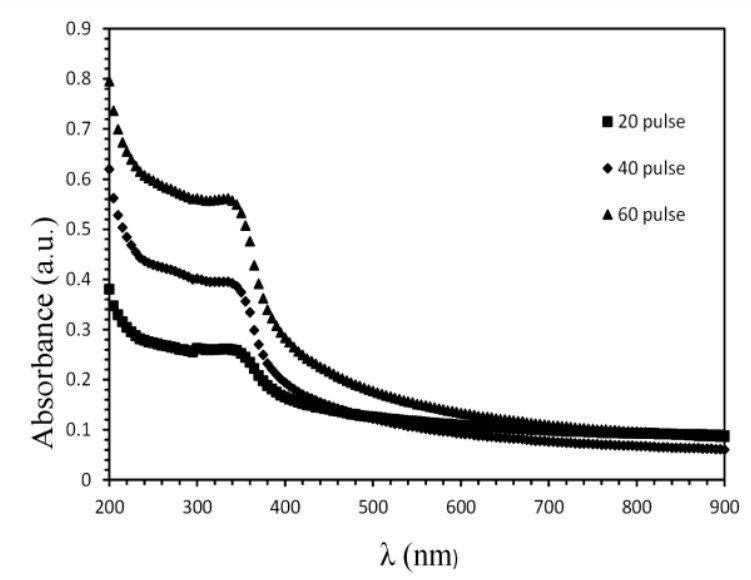

Fig.(6): optical density of $\mathrm{ZnO}$ nanoparticles as a function of wavelength for 20, 40, and 60 pulses.

The optical energy gap $\left(E_{g}^{o p}\right)$ can be calculated for $\mathrm{ZnO}$ nanoparticles from Fig. (7). The extrapolation of the linear part at the absorption edge gives $E_{g}^{o p}=3.2 \mathrm{eV}$ which is in agreement with result obtained from the photoluminescence spectrum. In the photoluminescence experiment, $\mathrm{ZnO}$ colloidal is excited with a wavelength $335 \mathrm{~nm}$, to the maximum original emission at $382 \mathrm{~nm}$ for $\mathrm{ZnO}$ nanoparticles. Application of Plank's equation $\left(E_{g}^{o p}=h c / \lambda_{c}\right)$ gives $E_{g}^{o p}=3.24 \mathrm{eV}$ as shown in Fig.(8). 


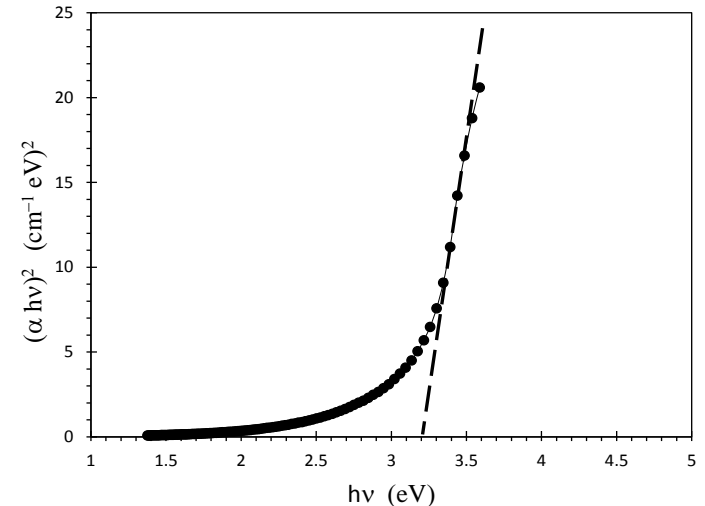

Fig.(7): Variation of $(\alpha h v)^{2}$ with hv for direct transition in Zno nanoparticles.

Blue emission notice in Photoluminescence spectra as shown in Figure 8, the mechanisms of blue emissions of $\mathrm{ZnO}$ were proposed with $\mathrm{Zn}$ interstitials-related defect levels as the $\mathrm{i}$ states [15].

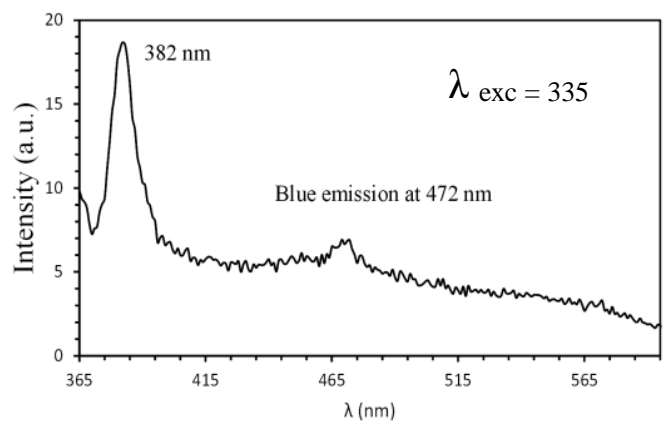

Fig.(8): Photoluminescence spectra of $\mathrm{ZnO}$ nanoparticles with wavelength excitation 335 nm.

In order to investigate the dynamics of the particle growth, the optical absorption was measured, is situ, as a function of time for particles growing in solution. As shown in Fig.(9) the Absorbance below $350 \mathrm{~nm}$ decrease with increase time. A shoulder at $350 \mathrm{~nm}$ indicates the excitonic peak of $\mathrm{ZnO}$ [7].

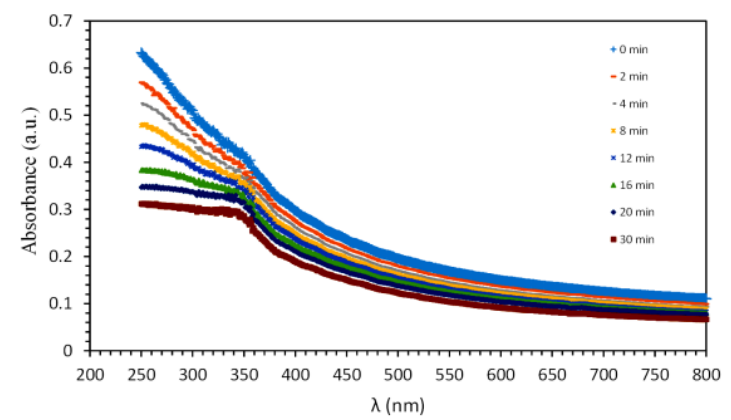

Fig.(9): Absorbance of $\mathrm{ZnO}$ nanoparticles produced by PLAL as a function of wavelength and time.
To investigate the surface morphology of $\mathrm{ZnO}$ film, optical microscope image was taking to $\mathrm{ZnO}$ Nanoparticles film deposited by electrostatic deposition method (20 KV DC voltage and $2 \mathrm{ml} / \mathrm{h}$ flow rate) as shown in Fig.(10), the surface of the film was examined by Atomic Force Microscopy (AFM) technique. Fig.(11) show the AFM images of $\mathrm{ZnO}$ NPs film. The roughness average is 3.02 $\mathrm{nm}$.

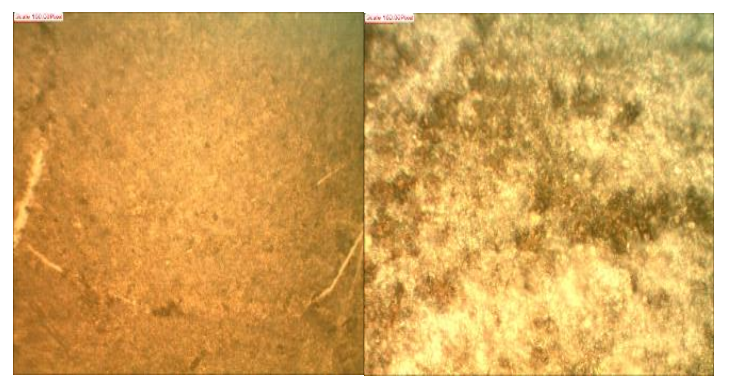

Fig.(10): optical microscope images of $\mathrm{ZnO}$ nanoparticles film deposited by electrostatic deposition method

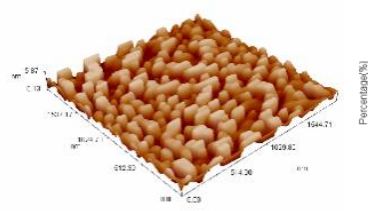

(a)

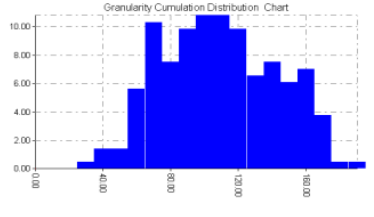

(b)
Fig.(11): AFM image of $\mathrm{ZnO}$ film deposited by electrostatic deposition method (a) and corresponding distribution chart (b).

The fill factor $(F F)$ is defined as

$F F=\frac{P_{\max }}{V_{o c} I_{s c}}=\frac{V_{\max } I_{\max }}{V_{o c} I_{S c}}$

where $P_{\max }$ is maximum power, $V_{o c}$ is open circuit voltage, $I_{S C}$ is short circuit current. The solar conversion efficiency $(\eta)$ is given by [16]:

$\eta=\frac{P_{\max }}{P_{S}}=\frac{F F V_{o c} J_{s c}}{P_{S}}$ 


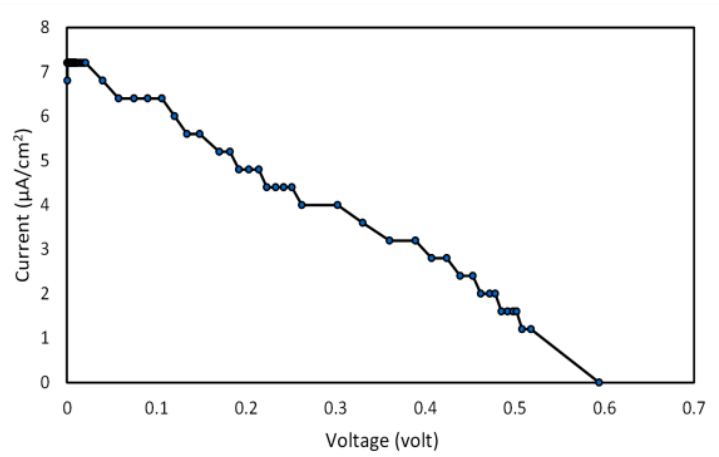

Fig.(12): Photovoltaic characteristic of DSSC based on $\mathrm{ZnO}$ nanoparticles.

where $P_{S}$ is the input solar irradiance (e.g., in $\mathrm{mW} / \mathrm{cm}^{2}$ ). Fig.(12) show the J-V characteristic of $\mathrm{ZnO}$ Dye-Sensitized Solar Cell. The output power for Dye-Sensitized Solar Cell as a function to output voltage is presented in and Fig.(14).

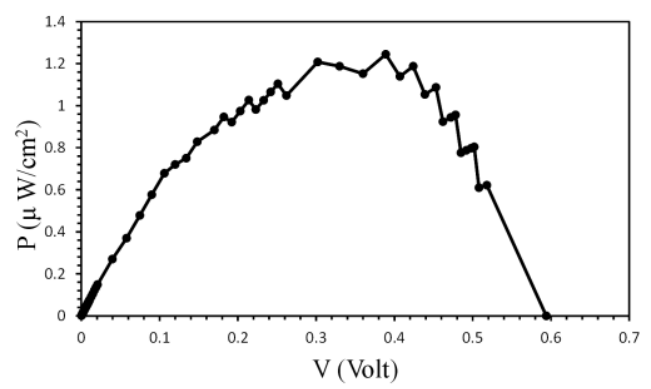

\section{Fig.(13): Power vs. potential for DSSC based on $\mathrm{ZnO}$ nanocrystalline}

Table (5) shows the I-V characteristics for $\mathrm{ZnO} \mathrm{DSSC}$, the main reason of very low efficiency is the thickness of photoanode $(\mathrm{ZnO}$ film) it's about $1 \mu \mathrm{m}$ while the thickness of regular DSSC is about $10 \mu \mathrm{m}$, the low yield of Laser ablation technique (in our Lab ) make thick film inaccessible. Also the porosity of the regular film allow the dye to reach large surface area of $\mathrm{ZnO}$, on the contrary the film obtained by direct deposition.

Table (5)

I-V characteristics for ZnO DSSC Studied in this work

\begin{tabular}{|c|c||c|c||c|}
\hline Sample & $\begin{array}{c}\mathbf{J}_{\text {sc }} \\
\left(\boldsymbol{\mu} \mathbf{A} / \mathbf{c m}^{2}\right)\end{array}$ & $\begin{array}{c}\mathbf{V}_{\text {oc }} \\
(\mathbf{V})\end{array}$ & $\mathbf{F F}$ & $\boldsymbol{\eta}(\%)$ \\
\hline \hline $\begin{array}{c}\text { ZnO } \\
\text { DSSC }\end{array}$ & 7.2 & 0.594 & 0.29 & 0.0016 \\
\hline
\end{tabular}

The electron lifetime $\left({ }^{\tau_{n}}\right)$ was obtained from Open Circuit Voltage Decay (OCVD) method is based on the reciprocal time derivative of the open-circuit voltage decay curve (Figure 14), normalized to the thermal voltage [17]

$\tau_{n}=-\frac{k_{B} T}{q}\left(\frac{d V_{o c}}{d t}\right)^{-1}$

Here $k_{B}$ is Boltzmann's constant, $T$ is the temperature, and $q$ is the elementary charge.

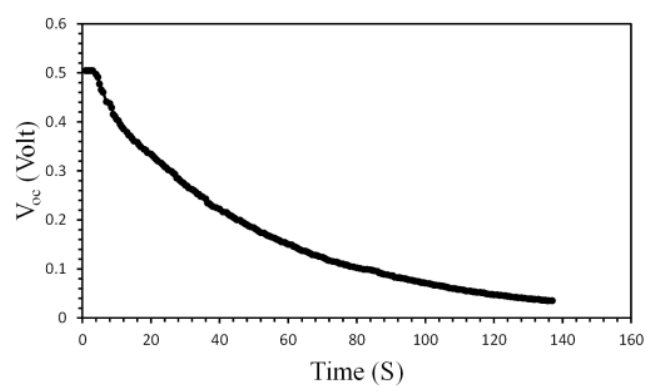

Fig.(14): Experimental $V_{\text {oc }}$ decay results of $\mathrm{ZnO}$ dye solar cell starting at initial steady state.

The trap distribution $(\alpha)$ can estimated from the following equation [18]:

$$
\frac{d V_{O C}(t)}{d \ln t} \approx \frac{k_{B} T / q}{1-\alpha}
$$

The semilogarithmic plot in Fig.(15) show the light intensity dependence of the open circuit voltage $V_{o c}$. For DSSC $V_{o c}$ depends linearly on the logarithm of the light intensity according to [19]:

$\frac{d V_{o c}}{d \ln \left(I_{0}\right)}=\frac{m k_{B} T}{q}$

The parameter $m$ is an empirical nonideality factor. Cells depart from idealdiode behavior, with nonideality factors higher than one. DSSC usually behave nonideally, although the origin of this nonideality is not clearly understood. It is often attributed to recombination via surface states In this case the density of electrons available for transfer to the redox couple varies with Fermi level in a way that depends on the surface state energy distribution. The ideality factor $m$ is related to the reaction order $(\beta)$ by

$$
m=\beta^{-1}
$$

The result of the equations $10,11,12$, and 13 were summarized in Table (6). 


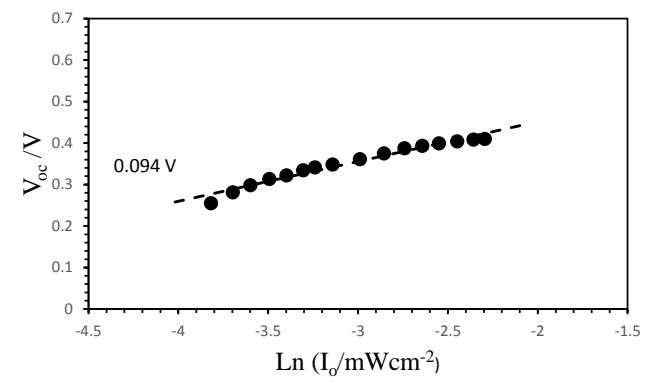

Fig.(15): Semilogarithmic plots of open circuit voltage vs light intensity for solar cell studied in this work. Slope in V is indicated in the graph.

Table (6)

Characteristic Parameters Transport and recombination of the $\mathrm{ZnO} D S S C$.

\begin{tabular}{|c||c||c||c||c||c|}
\hline Cell & $\begin{array}{c}V_{\text {oc VS }} \\
\text { light (V) }\end{array}$ & $\mathbf{m}$ & $\boldsymbol{\beta}$ & $\boldsymbol{\alpha}$ & $\begin{array}{c}\boldsymbol{\tau}_{\mathbf{n}} \\
(\mathbf{s})\end{array}$ \\
\hline \hline $\begin{array}{c}\text { ZnO } \\
\text { DSSC }\end{array}$ & $0.094 \mathrm{~V}$ & 3.65 & 0.274 & 0.85 & 8 \\
\hline
\end{tabular}

\section{Conclusions}

$\mathrm{ZnO}$ nanocrystals were successfully synthesized by laser ablation technique and characterized by XRD and TEM. The Line breadth due to the nanosized crystallite and strain was analyzed by Scherrer's equation.

W-H plot employed to analyze the size and strain contributions to line breadth. Optical properties of $\mathrm{ZnO}$ nanoparticles characterized by UV-Vis and PL Analysis. DSSC based on $\mathrm{ZnO}$ nanocrystalline have been fabricated and characterized, the cell parameter was summarized in two tables.

\section{References}

[1] José A. R. and Marcos Fernández-García, "SYNTHESIS, PROPERTIES, AND APPLICATIONS OF OXIDE NANOMATERIALS" John Wiley \& Sons, Inc., 2007.

[2] Seung H. K., Daeho L., Hyun W. K., Koo H. N., Joon Y. Y., Suk J. H., Costas P. G., and Hyung J. S., "Nanoforest of Hydrothermally Grown Hierarchical $\mathrm{ZnO}$ Nanowires for a High Efficiency DyeSensitized Solar Cell" Nano Lett., 11, 666, 2011.

[3] Debabrata P. and K.T. Leung, "Templatefree single-step electrochemical synthesis of
$\mathrm{ZnO}$ hollow nanospheres: Self-assembly of hollow nanospheres from nanoparticles" J.Mater. Chem., 19, 4902, 2009.

[4] Garinc G., Fernando E., Carlos J. P., Ricardo E. M., Francisco M., Dietmar Leinen, Jose $\mathrm{R}$ Ramos-Barrado, and Enrique A Dalchiele, " $\mathrm{ZnO}$ nanorod/CdS nanocrystal core/shell-type heterostructures for solar cell applications" Nanotechnology, 22, 505401, 2011.

[5] Zhi W. A., Yun W., Hao W., Ti W., Chao C., Yang X. and Chang L., "Enhanced band-edge photoluminescence from $\mathrm{ZnO}$ passivated $\mathrm{ZnO}$ nanoflowers by atomic layer deposition" Nanoscale Research Letters, 8, 105, 2013.

[6] Haibo Z., Weiping C., Yue L., Jinlian H., and Peisheng L., "Composition/Structural Evolution and Optical Properties of $\mathrm{ZnO} / \mathrm{Zn}$ Nanoparticles by Laser Ablation in Liquid Media" J. Phys. Chem. B, 109, 18260, 2005.

[7] Jeong M. C., Jae K. S., and Seung M. P., "Characterization of $\mathrm{ZnO}$ Nanoparticles Grown by Laser Ablation of a Zn Target in Neat Water" Bull. Korean Chem. Soc., 30(7), 2009.

[8] Guowel Y. "Laser Ablation in Liquids: Principles and Applications in the Preparation of Nanomaterials" Pan Stanford Publishing Pte. Ltd., 2012.

[9] Bindu P. and Sabu T., "Estimation of lattice strain in $\mathrm{ZnO}$ nanoparticles: $\mathrm{X}$-ray peak profile analysis" J Theor Appl Phys, 8, 123, 2014.

[10] Mario B., Paul F. F., and Christoph G. "Thin Film Analysis by X-Ray Scattering" WILEY-VCH Verlag GmbH \& Co., 2006.

[11] Mote VD., Purushotham Y., and Dole BN., "Williamson-Hall analysis in estimation of lattice strain in nanometersized ZnO particles" Journal of Theoretical and Applied Physics, 6, 2, 2012.

[12] Kelsall R. W., Hamley I. W., Geoghegan M., Nanoscale Science and Technology 2005 John Wiley \& Sons Ltd.

[13] Charles P. P., Jr. Frank J. O., "Introduction to Nanotechnology" John Wiley \& Sons, Inc., 2003.

[14] Velumani S., Xavier M., Sebastian P.J., "Structural and optical characterization of hot wall deposited $\mathrm{CdSe}_{\mathrm{x}} \mathrm{Te}_{1-\mathrm{x}}$ films" Solar 
Energy Materials \& Solar Cells, 76, 359, 2003.

[15] Guowei Y., "Laser Ablation in Liquids: Principles and Applications in the Preparation of Nanomaterials" Pan Stanford Publishing Pte. Ltd., 2012.

[16] Brian O. and Michael G., "A low-cost, high-efficiency solar cell based on dyesensitized colloidal $\mathrm{TiO}_{2}$ films" Nature, 353, 737, 1991.

[17] Ansari-Rad M., Abdi Y., and Arzi E., "Reaction Order and Ideality Factor in DyeSensitized Nanocrystalline Solar Cells: A Theoretical Investigation" J. Phys. Chem. C, 116, 10867, 2012.

[18] Guillen E., Peter L. M., and Anta J. A., "Electron Transport and Recombination in ZnO-Based Dye-Sensitized Solar Cells" J. Phys. Chem. C, 115(45), 22622, 2011.

[19] Nazeeruddin Md. K., Etienne Baranoff, Michael G., "Dye-sensitized solar cells: A brief overview" Solar Energy, 85, 1172, 2011.

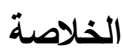

تم تحضير اوكسيد الزنلك ذو البنية البلوربة والحجم النانوي

باستخدام طريقة القع الليزري لمعدن الزنك النقي المغمور في

ماء عالي النقاوة. تحليل الاشعة السينية اظهر ان الجسيمات

النانوبة لاوكسيد الزنلك تمنلك بنية بلورية من الطور

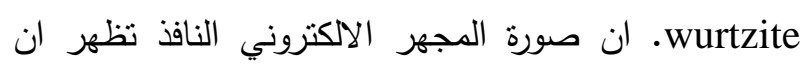

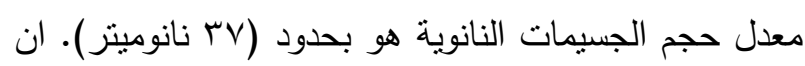

مخطط ويلمسون- هول وُظِّفَ لحساب الاحجام البلورية

وإجهاد الثبيكة. فجوة الطاقة البصرية المحسوبة من طيف

الاشعة فوق البنفسجية - المرئية تتفق مع فجوة الطاقة

المحسوبة من طيف التلألؤ الضوئي، الانبعاث الازرق تم

رصده عندما هيجت العينة ضوئيا بضوء ذو طول موجي

(OTس نانوميتز) ) ت تم تصنيع خلية شمسية صبغية بنجاح من

غشاء اوكسيد الزنلك النانوي المرسب باستخدام تقنية الترسيب

الكهروستاتيكي. 